Sari Pediatri, Vol. 6, No. 1, Juni 2004: 47-51

\title{
Terapi Diet pada Autisme
}

\author{
Sri Alemina Ginting, Ani Ariani, Tiangsa Sembiring
}

\begin{abstract}
Autisme merupakan suatu jenis gangguan perkembangan anak yang kompleks dan berat, yang tampak sebelum usia 3 tahun. Insiden kelainan ini akhir - akhir ini meningkat. Penyebab pasti belum diketahui, diduga multifaktor. Terungkap adanya hubungan antara gangguan pencernaan dan gejala autisme. Sekitar $60 \%$ penyandang autisme mempunyai sistem pencernaan yang tidak sempurna. Beberapa waktu yang lalu autisme dikatakan merupakan penyakit yang tidak dapat "disembuhkan", tetapi saat ini ada beberapa kasus mengalami perbaikan dramatis dengan melakukan terapi diet bebas kasein dan glutein.
\end{abstract}

Kata kunci: autisme, gangguan pencernaan, diet kasein dan glutein

A utisme merupakan suatu istilah yang masih asing bagi sebagian besar masyarakat, bahkan masih cukup banyak para profesional yang belum bisa mengenalinya apalagi mendiagnosis keadaan ini, sehingga sering terjadi salah tata laksana. ${ }^{1,2}$ Beberapa tahun terakhir ini terjadi peningkatan angka kejadian autisme di seluruh dunia. Pada tahun 1966 prevalensi autisme hanya 4,5 per 10.000 anak. Penelitian terakhir menunjukkan angka 1 per 1000 anak, bahkan ada yang melaporkan 1 per 150 anak. Di Indonesia belum ada angka yang tepat mengenai angka kejadian autisme. 3,4

Autisme adalah suatu jenis gangguan perkembangan pervasif anak yang kompleks dan berat yang tampak sebelum usia 3 tahun. Keadaan ini menyebabkan mereka tidak mampu berkomunikasi, mengekspresikan perasaan maupun keinginannya, sehingga perilaku dan hubungan dengan orang lain

\footnotetext{
Alamat Korespondensi:

Dr. Ani Ariani, SpA.

Kepala Subbagian Gizi. Bagian Ilmu Kesehatan Anak FK USU/RS HAM Jalan Bunga Lau No. 17

Telepon: (061) 8361721, Fax: (061) 8361721 Medan.

Dr. Sri Alemina Ginting PPDS IKA FK - USU / RSHAM, Bagian Ilmu Kesehatan Anak, Medan.
}

terganggu. ${ }^{3}$ Penyebab autisme saat ini belum diketahui dengan pasti, diduga multifaktor. ${ }^{4,5}$ Akhir - akhir ini dari penelitian terungkap hubungan antara gangguan pencernaan dan gejala autisme. Sekitar $60 \%$ penyandang autisme mempunyai sistem pencernaan yang kurang baik, sehingga beberapa jenis makanan tertentu tidak dapat dicerna dengan sempurna. Hasil pencernaan yang tidak sempurna tersebut dapat merusak otak sehingga memperberat gejala autisme. ${ }^{6,7}$

Di Indonesia, dari hasil pemeriksaan terhadap 200 anak dengan gejala autisme, didapatkan bahwa seluruhnya menderita alergi makanan (multiple food allergy). Sekitar $95 \%$ alergi terhadap susu sapi dan jenis gandum. 6,8 Tata laksana penyandang autisme bertujuan untuk meminimalkan gejala dan menumbuhkan perilaku yang normal. Gejala autisme sangat beragam, sehingga tidak mungkin pasien hanya ditangani dengan satu jenis terapi saja. Dibutuhkan terapi terpadu bagi setiap kasus. ${ }^{7}$ Beberapa waktu yang lalu dikatakan bahwa autisme merupakan penyakit yang tidak dapat disembuhkan, tetapi saat ini ada beberapa kasus yang memperoleh penyembuhan yang dramatis. Beberapa anak menunjukkan respons yang baik terhadap stimulasi fisik yang intensif, beberapa anak yang lain berespons terhadap pendengaran. Saat ini telah dilaporkan perkembangan yang dramatis terhadap anak yang melakukan terapi diet bebas kasein dan glutein ${ }^{8}$ 


\section{Kelainan yang Dapat Dijumpai pada Penyandang Autisme}

\section{Gangguan fungsi enzim}

Berbagai penelitian telah mendapatkan hasil bahwa sistem enzim sulfotransferase tidak berfungsi dengan baik pada penyandang autisme. Hal ini mempengaruhi metabolisme secara luas. Anak dengan defisiensi enzim ini tidak dapat memetabolisme makanan dan zat kimia yang mengandung fenol (pewarna) dan amin (apel, jeruk, asam sitrat, parasetamol, coklat) dengan sempurna. Phenol sulfur transferase berperan penting dalam memecah hormon, komponen beberapa makanan, dan zat toksik dalam tubuh. Bila terjadi defisiensi enzim ini tubuh tidak dapat mendetoksifikasi zat toksik tersebut. ${ }^{9}$ Terganggunya fungsi enzim ini dapat menyebabkan kebocoran dinding usus (leaky gut) sehingga mengakibatkan absorpsi protein yang tidak sempurna, seperti kasein dan glutein. Kasein adalah fosfoprotein dari susu yang memiliki struktur molekul yang mirip dengan glutein, sedangkan glutein merupakan protein yang terdapat pada tumbuhan monocotyledone. Tumbuhan ini meliputi gandum dan turunannya (wheat, oats, rye, barley). ${ }^{10-14}$

\section{Pertumbuhan jamur yang berlebihan}

Dari penelitian didapatkan bahwa kira - kira 50\% penyandang autisme mengalami pertumbuhan jamur (candida) yang berlebihan pada usus. ${ }^{5,10}$ Candida yang berproliferasi dalam saluran cerna dapat mengalami perubahan anatomi dan fisiologi menjadi jamur yang berbeda, disebut mycelial fungus, yang dapat merusak dinding usus. ${ }^{10}$ Keadaan ini dapat diperberat oleh pemakaian antibiotik yang sering. Antibiotik dapat mengganggu keseimbangan flora normal usus. Dikatakan penyandang autisme rentan terhadap infeksi, seperti infeksi telinga tengah, radang tenggorokan, diare, dan lain - lain. Untuk mengatasi pertumbuhan jamur yang berlebihan harus dicegah pemakaian antibiotik yang berlebihan, menghindari makanan yang membuat pertumbuhan jamur bertambah subur (misalnya gula, ragi), dan menjaga keseimbangan flora normal usus. ${ }^{13}$

\section{Analisis urin}

Beberapa penelitian menyebutkan bahwa terdapat variasi yang nyata tentang kandungan peptida pada urin normal dengan urin penyandang autisme. Analisis urin penyandang autisme menunjukkan 2 puncak utama yang tidak dijumpai pada urin anak normal. Puncak pertama diidentifikasi sebagai betacasomorphin yang berasal dari susu, sedang puncak ke-dua diduga merupakan peptida dari glutein. Sekitar $70-80 \%$ penyandang autisme menunjukkan peningkatan kadar zat - zat tersebut di atas. ${ }^{14}$ Betacasomorphin tidak terlihat lagi dalam urin setelah semua bahan makanan yang terbuat dari susu dihilangkan dari diet, sementara peptida dari glutein masih tetap terdeteksi di dalam urin, meskipun diet bebas glutein sudah dijalankan. Pada percobaan di Inggris didapatkan bahwa pengurangan kadar peptida glutein dalam urin hanya terjadi sebesar $26 \%$, setelah selama 5 bulan diet bebas glutein. Hal ini disebabkan karena peptida glutein dapat masuk ke dalam jaringan tubuh. ${ }^{9}$

\section{Teori peningkatan opioid (opioid excess theory)}

Pada tahun 1980 sejumlah peneliti melihat adanya kemiripan antara efek opioid terhadap perilaku binatang dengan gejala pada penyandang autisme. Ada juga teori yang mengatakan bahwa pada penyandang autisme terdapat peningkatan kadar opioid di dalam otak yaitu beta endorphins yang disebut dengan runner's high. Hal ini dibuktikan dengan adanya peningkatan kadar bahan serupa endorphin di dalam cairan likuor serebrospinalis pada beberapa penyandang autisme, terutama yang tahan terhadap rangsang sakit dan menunjukkan perilaku melukai diri sendiri (selfinjury). ${ }_{6,8}$ Beberapa penelitian mendukung hipotesis bahwa autisme merupakan hasil kerja peptida yang mempengaruhi neurotransmiter di susunan saraf pusat. Peptida (caseomorphin dan gluteomorphin) yang ikut dalam peredaran darah dapat menembus sawar darah otak dan menduduki reseptor opioid, menyebabkan sistem saraf pusat terganggu, seperti fungsi persepsi, kognitif, emosi, tingkah laku, dan lain - lain. Adanya opioid juga mempengaruhi sistem imun penyandang autisme. ${ }^{10}$ Pada anak normal kadar peptida di usus sangat rendah dan yang mencapai susunan saraf pusat juga sangat rendah, sehingga efeknya dapat diabaikan. ${ }^{15}$

Beberapa cara untuk mengatasi hal tersebut di atas dapat dilakukan dengan pengobatan anti opioid yaitu naltrexon. Pemberian obat tersebut dapat mengurangi gejala gangguan sistem saraf pusat, hanya saja obat ini 
rasanya sangat pahit sehingga sering dimuntahkan oleh anak - anak. Cara lain yang tidak kalah penting adalah dengan melakukan diet bebas kasein dan glutein pada $\operatorname{anak}^{6,8}$

\section{Terapi Diet pada Penyandang Autisme}

\section{Diet bebas kasein dan glutein}

Tidak semua anak autisme harus menjalani diet bebas kasein dan glutein. Dr Paul Shattock ${ }^{10}$ menemukan bahwa lebih dari $50 \%$ populasi autisme pada tubuhnya terdapat substansi yang sifatnya mirip dengan peptida opioid. Untuk mengetahui apakah anak perlu menjalani terapi diet, dapat dilakukan pemeriksaan feses, urin, darah, rambut. ${ }^{11}$ Pemeriksaan tersebut memerlukan biaya yang sangat mahal. Salah satu cara yang mudah dan biaya murah adalah dengan melakukan diet bebas kasein dan glutein pada anak. Selanjutnya dipantau ada tidaknya perbaikan pada anak tersebut, dengan mencatat bahan makanan apa saja yang diberikan kepada anak dan perubahan reaksi yang muncul. Bila pada saat anak mendapat bahan makanan tersebut terlihat peningkatan perilaku autisme, maka diduga kuat anak menderita alergi terhadap makanan tersebut. Cara ini mempunyai kelemahan, yaitu tidak memungkinkan untuk menguji semua bahan makanan sekaligus. ${ }^{10,12}$

Indikasi terapi diet pada penyandang autisme, ${ }^{16}$

- Gangguan bicara yang berat.

- Pada tahun pertama perkembangan anak normal, tetapi selanjutnya anak mengalami kemunduran yang nyata dalam perkembangannya.

- Gangguan buang air besar.

- Sering mendapat pengobatan dengan antibiotik

- Sering merasa haus

- Banyak mengkonsumsi produk susu dan gandum.

- Pucat

- Bayangan yang gelap di kelopak mata bawah

- Kongesti nasal yang persisten

- Warna kulit kemerahan di sekitar anus

- Eksim

\section{Cara melakukan diet}

Diet tidak dapat dilakukan sembarangan dengan menghilangkan makanan tertentu begitu saja. Sebelum melakukan diet, sebaiknya ditambahkan makanan lain yang diperbolehkan, sehingga anak tidak kekurangan zat gizi dan mencoba makanan yang baru. Menghilangkan makanan yang mengandung susu dan gandum berarti mengurangi pemasukan vitamin dan mineral, oleh karena itu anak harus diberi cukup suplementasi vitamin dan mineral. ${ }^{6}$ Diet harus dilakukan secara bertahap, mula - mula hanya makan malam, kemudian makan pagi dan selanjutnya makan siang, dan akhirnya juga makanan selingan. Bila diet dilakukan sekaligus akan timbul efek withdrawal. Efek withdrawal biasanya tidak lama, akan tetapi bisa sangat parah terutama pada anak yang lebih muda. ${ }^{6,9}$

Tahapan diet dapat dilakukan dengan mengikuti protokol Sunderland. Protokol ini membagi diet dalam 3 tahap yaitu ${ }^{9,17}$

1. Tahap gencatan senjata (cease fire)

- Membuang kasein dari makanan dalam 3 minggu.

- Membuang gluten dari makanan dalam 3 bulan.

2. Tahap perundingan awal (preliminary agreement)

- Membuat catatan harian makanan (food diary) untuk melihat makanan apa saja yang menyebabkan perubahan perilaku pada anak selain kasein dan gluten (telur, kacang, jagung, kedelai, tomat, dan lain sebagainya).

- Melakukan pemeriksaan laboratorium untuk mengetahui kadar mineral, vitamin dalam tubuh. Berikan suplementasi bila ada kekurangan.

- Pemeriksaan mikro organisme dalam usus (jamur, parasit, bakteri)

3. Membangun kembali secara aktif (active reconstruction)

- Koreksi kekurangan sulfat

- Mengaktifkan enzim dengan memberikan tri methyl glycine (TMG)

Diperkirakan pada penyandang autisme terjadi penurunan asam lambung, akibatnya enzim yang bekerja di lambung tidak dapat berfungsi dengan baik. Tri methyl glycine berfungsi menambah kadar asam lambung.

- Pemberian asam lemak tak jenuh, seperti evening primrose oil, fish oil, cold liver oil.

- Pemberian L-glutamin akan memperkuat kekebalan tubuh dan membantu penyembuhan dinding usus. Glutamin juga 
mempunyai efek meningkatkan fungsi mental dan memperbaiki otot-otot skeletal. Dikatakan juga glutamin mengurangi keinginan yang berlebihan untuk mengkonsumsi gula.

- Suplementasi enzim. (Tabel 1)
Disampaikan pada Lokakarya Penatalaksanaan Anak Autistik, Cilandak, 23 November, 1999.

2. Pusponegoro HD. Autisme, bagaimana mengenal dan menegakkan diagnosa. Dalam: Trihono PP, Purnamati S, Syarif DR, penyunting. Hot Topic in pediatrics II.

Tabel 1. Bahan makanan yang harus dihindari dan bahan makanan pengganti ${ }^{8}$

\begin{tabular}{ll}
\hline Hindari & \multicolumn{1}{c}{ Pengganti } \\
\hline Susu sapi dan olahannya & Susu kedelai, susu kentang, kacang hijau, air tajin \\
Tepung terigu, oats & Tepung beras merah, tepung beras, tepung kedelai \\
Kacang tanah, almond & Kacang mete, walnut, biji labu kuning \\
Garam & Gunakan setengah bagian dari yang tertera dalam resep \\
Gula pasir & Fruktosa, madu \\
\hline
\end{tabular}

Evaluasi sebaiknya dilakukan setelah menjalani diet selama setahun, tetapi ada juga ahli yang mengatakan untuk anak berusia kurang dari 6 tahun harus melakukan diet selama 3 bulan, sedangkan anak berusia lebih dari 6 tahun, paling sedikit 6 bulan melakukan diet baru dapat dievaluasi. ${ }^{6,18}$ Manfaat yang diperoleh adalah mereka seperti keluar dari keadaan yang berkabut, indra mereka mulai bekerja, hiperaktif berkurang, lebih dapat merasakan nyeri, serta lebih patuh. ${ }^{6}$ Dari suatu penelitian pada 22 penyandang autisme yang menjalani diet dilaporkan terjadi peningkatan komunikasi verbal dan non verbal, emosi, kemampuan motorik, hiperaktif berkurang, dan terjadi perubahan pola tidur. ${ }^{18}$

\section{Kesimpulan}

Autisme adalah suatu jenis gangguan perkembangan pervasif pada anak yang kompleks dan berat, yang tampak sebelum usia 3 tahun. Insidens autisme akhir - akhir ini makin tinggi. Penyebab pasti belum diketahui, diduga multifaktor. Gejala autisme beragam sehingga diperlukan beberapa jenis terapi untuk menanganinya. Satu di antaranya adalah dengan terapi diet bebas kasein dan glutein. Beberapa penelitian telah menunjukkan bahwa terapi diet dapat memperbaiki keadaan anak.

\section{Daftar Pustaka}

1. Widyawati I. Kriteria diagnostik gangguan autistik.
Pendidikan Kedokteran Berkelanjutan Ilmu Kesehatan Anak XLV, 18 -19 Febuari, Jakarta. Balai penerbit FK UI 2002. .h. $47-62$.

3. American Academy of Pediatrics, Committee on children with disabilities. The pediatricians role in the diagnosis and management of autistic spectrum disorder in children. Didapat dari: URL: http//www.pediatrics.org/ cgil content/full/107/5/e85.

4. Courchesne RY. From imposse to insight in autism research from behavioral symptoms to biological explanations. Developmental and psychopathology 1999;9: 389-419.

5. Pusponegoro HD. Penyebab dan neuropatologi autisme. Disampaikan pada Lokakarya Penatalaksanaan Anak Autistik, Cilandak, 23 November, 1999

6. Budhiman M. Autisme dan gangguan pencernaan. Buletin Yayasan Autisme 2002, Oktober 2002; halaman $1-2$.

7. Budhiman M. Prinsip terapi dan rehabilitasi anak autistik. Disampaikan pada Lokakarya Penatalaksanaan Anak Autistik, Cilandak, 23 November, 1999.

8. Lewis LS. Autism. Dalam: Lewis LS, penyunting. Special diets for special kids: Understanding and implemetating a glutein and kasein free diet to aid in the treatment of autism and related developmental disorders. San Diego: Future Harians Inc, 1998.h.24-56.

9. Shattock P, Whiteley P. Urutan langkah intervensi biomedik untuk penanganan autis dan sejenisnya. Disampaikan pada Seminar Intervensi Biomedis pada Gangguan Autisme dan Sejenisnya. Jakarta, 20 Maret 2001.

10. Shattock P. Can dietary intervention be used succesfully as a therapy for autism. Disampaikan pada Durham 
Sari Pediatri, Vol. 6, No. 1, Juni 2004

Conference, Amerika Serikat, 1995

11. Gunawan H, Tanjung N. Terapi diet pada autisme. Disampaikan pada Seminar Gangguan Metabolisme dan Intervensi Biomedik pada Penyandang Autisme. Bandung, 21 Oktober 2001.

12. Edelson SM. "Leaky gut" and the glutein/ casein free diet. Didapat dari: URL: http://www.autism.org/leaky gut. Html.

13. Bingham M. Autism and human GUT mikroflora. Didapat dari: URL: http://www.fst.rdg.ac.ukk/research/ fmsulautism.htm.

14. Shattock P, Savery D. Evaluation of urinary profiles obtained from people with autism and associated disorders Part 1: Classification of sub groups. Disampaikan pada Durham Conference. Amerika Serikat, 1997.

15. Shattock $\mathrm{P}$, Whitely P. Bridging the gap - opioid peptida and executive function. Disampaikan pada Durham Conference. Amerika Serikat, 1998.

16. Lewis LS. An experimental intervention for autism. Didapat dari: URL: http://www.special foods.com/CIP.Aut - Diet.html.

17. Budhiman M. Sekilas mengenai penanganan biomedik. Disampaikan pada Seminar Intervensi Biomedis pada Gangguan Autisme \& Sejenisnya, Jakarta, 20 Maret 2001.

18. Slimak KM. The special food comprehensive intervension program and 'the special food diet' for autistic individuals. Didapat dari: URL: http://www.special foods.com.CIP -Aut Diet. html. 